\title{
PROFIL KEBUGARAN AWAL MEMBER BARU PRIA USIA 20-25 di FITNESS CENTER GEDUNG OLAHRAGA FIK-UNY
}

Oleh:

Suharjana dan Gilang Anggarkusuma

Jurusan Pendidikan Kesehatan dan Rekreasi FIK-UNY

\section{Abstrak}

Penelitian ini bertujuan untuk mengetahui profil kebugaran awal member baru pria Fitness Center Gedung Olahraga Fakultas Ilmu Keolahragaan Universitas Negeri Yogyakarta (GOR FIK UNY), meliputi pengukuran daya tahan jantung paru, kelentukan, kekuatan otot, dan lemak. Analisis profil kebugaran memudahkan penentuan program yang tepat.

Penelitian ini merupakan penelitian deskriptif menggunakan metode survei. Sampel dalam penelitian ini adalah member baru pria fitness center GOR FIK UNY yang berjumlah 20 orang, dengan instrumen yang digunakan berupa tes dan pengukuran. Instrumen yang digunakan merupakan tes yang telah standar. Komponen tes yang diukur yaitu daya tahan jantung paru, fleksibilitas, kekuatan otot, dan lemak. Untuk menganalisis data digunakan teknik deskriptif kuantitatif dengan persentase.

Hasil penelitian menunjukkan profil kebugaran awal member baru pria umur 20-25 Fitness Center Gedung Olahraga Fakultas Ilmu Keolahragaan Universitas Negeri Yogyakarta (GOR FIK UNY) berdasarkan tes daya tahan jantung paru masuk dalam kategori sangat buruk sebanyak 11 orang $(55 \%)$, kategori buruk sebanyak 3 orang $(15 \%)$, kategori cukup sebanyak 4 orang $(20 \%)$, kategori baik dan superior sebanyak 1 orang $(5 \%)$, dan tidak ada yang masuk dalam kategori excellent. Berdasarkan tes kelentukan masuk dalam kategori kurang sebanyak 11 orang (55\%), kategori baik sebanyak 5 orang $(25 \%)$, kategori bagus sebanyak 4 orang $(20 \%)$, dan tidak ada yang masuk dalam kategori luar biasa dan sangat bagus. Berdasarkan tes kekuatan otot masuk dalam kategori sangat kurang sebanyak 9 orang (45\%), kategori kurang sebanyak 5 orang $(25 \%)$, kategori cukup sebanyak 6 orang $(30 \%)$, dan tidak ada yang masuk dalam kategori istimewa dan baik. Berdasarkan tes lemak masuk dalam kategori lemak sangat tinggi atau sangat gemuk sebanyak 5 oarang $(25 \%)$, kategori lemak tinggi atau gemuk sebanyak 3 orang $(15 \%)$, kategori normal sebanyak 7 orang $(35 \%)$, kategori kurus sebanyak 2 orang $(10 \%)$, dan kategori sangat kurus sebanyak 3 orang $(15 \%)$. Dari penelitian ini dapat disimpulkan bahwa profil kebugaran awal member baru pria Fitness Center GOR FIK UNY Yogyakarta masih kurang baik, sehingga dibutuhkan pemberian program yang tepat.

Kata Kunci: member fitness center, profil kebugaran. 
Tingkat kebugaran yang dimiliki seseorang dapat dijadikan salah satu tolak ukur seseorang, apakah seseorang itu bugar atau tidak. Dalam melakukan latihan beban, seseorang ingin mendapatkan tubuh yang bugar, sehat, indah, dan proporsional. Keadaan itu tidak semuanya langsung didapatkan seseorang yang baru berlatih dengan latihan beban. Seseorang masuk atau mendaftar di fitness center untuk pertama kali tidak semuanya dalàm keadaan bugar. Dari daya tahan jantung paru, kelentukan, kekuatan otot, lemak akan diukur untuk mengetahui profil kebugaran seorang member.

Profil kebugaran ini berguna untuk mengetahui keadaan seorang member dan ketepatan dalam memberikan program latihan yang baik untuk member tersebut. Profil merupakan salah satu komponen penting pada individu atau organisasi. Profil dapat diartikan sebagai rupa, penampilan yang kelihatan. Profil lebih dipengaruhi individu/organisasi itu sendiri. Profil lebih cenderung dilihat dari segi fisik yang terlihat. Fisik meliputi, seluruh komponen yang ada pada individu/organisasi itu sendiri. Profil yang ada pada individu juga bisa dilihat dari perilaku keseharian individu tersebut. Profil dapat dipengaruhi oleh gaya hidup seseorang ataupun aktivitas yang dilakukannya sehari-hari. Beberapa hal yang dapat mempengaruhi suatu profil seseorang antara lain dari makanan yang dikonsumsi dan aktivitas sehari-hari. Profil kebugaran tersebut diambil dari komponen kebugaran yang ada, seperti kekuatan, kelentukan, daya tahan, lemak, dan lain-lain. Profil kebugaran ini digunakan untuk mengetahui tingkat kebugaran yang dimiliki seseorang, dan hal ini sangat dibutuhkan seorang instruktur fitness untuk memberikan program latihan yang tepat.

Profil kebugaran dapat dijadikan sebagai gambaran umum kebugaran seseorang. Gambaran suatu kondisi ini sangat penting bagi setiap individu, karena dari gambaran itu seseorang dapat mengetahui apakah dia bugar atau tidak, program latihan apa yang baik untuk dilakukan, apa yang harus ditingkatkan dalam dirinya, dan membantu seorang instruktur agar tidak salah dalam memberikan suatu program latihan. Keadaan ini membantu seseorang lebih fokus dan lebih mudah mendapatkan tujuannya.

Banyaknya fitness center atau pusat-pusat kebugaran, membantu dan memudahkan dalam mencapai tujuan tersebut, karena tempat tersebut menyediakan berbagai macam variasi alat sehingga variasi latihan dapat dilakukan dan menghindarkan dari kebosanan. Salah satu fitness center di Yogyakarta yang tempatnya luas, alatnya lengkap dan bervariasi serta biayanya murah adalah Fitness Center Gedung Olahraga Fakultas Ilmu Keolahragaan Universitas Negeri Yogyakarta (GOR FIK UNY). Di samping itu berbagai macam program latihan ditawarkan seperti hipertrofi otot, penurunan dan penambahan berat badan, kebugaran, pengencangan otot dan rehabilitasi penyakit dan cidera.

Fitness Center GOR FIK UNY Yogyakarta merupakan salah satu fitness center terbaik di Yogyakarta. Fasilitas fitness yang baik dilengkapi dengan alat-alat fitness lengkap. Alat fitness yang dimiliki oleh Fitness Center GOR FIK UNY Yogyakarta telah menggunakan alat-alat modern. Alat fitness dari Technogym yang dimiliki Fitness Center GOR FIK UNY telah menggunakan panel digital, dilengkapi dengan tiga treadmill otomatis dan enam 
buah sepeda statis. Ruang fitness yang nyaman dan bersih dilengkapi dengan AC. Tempat istirahat yang bersih dan nyaman dilengkapi dengan shower room. Tempat parkir yang luas dan aman memberikan rasa nyaman dan aman member. Posisi Fitness Center GOR FIK UNY yang berada di dekat jalan raya memberikan kemudahan akses untuk masuk. Karyawan dan karyawati yang ramah memberikan kenyamanan lebih, dan keunggulan yang lain, yaitu instruktur profesional dengan dasar keilmuan ilmu keolahragaan yang seluruhnya merupakan lulusan dari Fakultas Ilmu Keolahragaan. Program latihan yang bervariasi, di antaranya physical fitness, fat lose, body shaping, weight gain, body building dan terapi pascacedera, dan harga yang terjangkau menjadikan Fitness Center GOR FIK UNY Yogyakarta cepat dikenal oleh masyarakat. Fitness center yang dibuka pertama kali tanggal 1 Maret 2009 ini mengadaptasi standar pelayanan yang mendekati standar pelayanan hotel. Setiap member di Fitness Center GOR FIK UNY Yogyakarta memiliki data profil kebugaran yang digunakan untuk mengetahui keadaan awal seorang member, memilih program yang tepat, dan memantau peningkatan yang dialami member.

Berdasarkan latar belakang di atas, penulis tertarik untuk mengadakan penelitian dengan judul "Profil kebugaran awal member baru pria umur 20-25 Fitness Center Gedung Olahraga Fakultas Ilmu Keolahragaan Universitas Negeri Yogyakarta."

\section{KAJIAN PUSTAKA}

\section{Kebugaran}

Menurut Djoko Pekik I (2000: 2) secara umum yang dimaksud kebugaran adalah kebugaran fisik (physical fitness), yakni: kemampuan seseorang untuk dapat melakukan kerja sehari-hari secara efisien tanpa menimbulkan kelelahan yang berlebihan, sehingga masih dapat menikmati waktu luangnya. Seseorang yang merasa sehat belum tentu bugar sebab untuk dapat mengerjakan tugas sehari-hari seseorang tidak hanya dituntut bebas dari penyakit saja, tetapi juga dituntut memiliki kebugaran.

Kebugaran yang dimiliki seseorang merupakan kemampuan seseorang melakukan kegiatan sehari-hari, dan kesehatan tubuh terjaga dengan baik. Tidak timbul rasa lelah yang berarti dan tidak timbul rasa sakit setelah melakukan suatu aktivitas yang cukup berat. Kebugaran tersebut sangat dipengaruhi oleh aktivitas sehari-hari, gaya hidup, dan pola makan seseorang.

Kebugaran sangat penting dalam menunjang aktivitas kehidupan sehari-hari, tetapi nilai kebugaran tiap-tiap orang berbeda-beda sesuai dengan tugas/profesi masing-masing. Menurut (Junusul Hairy. (1989) kebugaran terdiri atas komponen-komponen yang dikelompokkan menjadi dua kelompok, kelompok pertama yang berhubungan dengan kesehatan (Health Related Physical Fitness) yang terdiri atas komposisi tubuh, kelentukan, kekuatan otot, daya tahan jantung paru,dan daya tahan otot. Lalu kelompok yang kedua berhubungan dengan keterampilan (Skill Related Physical Fitness) yang terdiri dari kekuatan, kelincahan, koordinasi, kecepatan, waktu reaksi, daya tahan otot, dan keseimbangan. Dalam skripsi ini 
hanya dijelaskan komponen kebugaran yang berkaitan dengan kesehatan. Komponen-komponen tersebut adalah sebagai berikut:

a. Komposisi Tubuh

Adalah persentase (\%) lemak dari berat badan total dan Indeks Massa Tubuh (IMT). Lemak cepat meningkat setelah berumur 30 tahun dan cenderung menurun setelah berumur 60 tahun. Obesitas pada anak-anak disebabkan oleh: hiperplasi dan hipertropi sel adiposit serta input berlebihan. Obesitas pada orang dewasa oleh: hiperplasi dan hipertrofi sel adiposit serta output yang kurang.

1) Kelenturan/Fleksibilitas Tubuh

Adalah luas bidang gerak yang maksimal pada persendian, tanpa dipengaruhi oleh suatu paksaan atau tekanan. Dipengaruhi oleh: Jenis sendi; Struktur tulang; Jaringan sekitar sendi, otot, tendon dan ligamen. Puncak kelenturan terjadi pada akhir masa pubertas. Kelenturan gerak tubuh dikarenakan meningkatkan efisiensi kerja otot. Orang yang kelenturannya tidak baik cenderung mudah mengalami cedera.

2) Kekuatan Otot

Adalah kontraksi maksimal yang dihasilkan otot, kemampuan untuk membangkitkan tegangan terhadap suatu tahanan. Untuk laki-laki $25 \%$ lebih besar daripada wanita.

3) Daya Tahan Jantung Paru

Adalah kemampuan jantung paru dan pembuluh darah berfungsi secara optimal pada waktu kerja dalam mengambil $\mathrm{O}_{2}$ secara maksimal $\left(\mathrm{VO}_{2} \mathrm{Max}\right)$ dan menyalurkannya ke seluruh tubuh terutama jaringan aktif, sehingga digunakan untuk proses metabolisme tubuh.

4) Daya Tahan Otot

Adalah kemampuan untuk kontraksi submaksimal secara berulangulang atau berkontraksi terus-menerus dalam waktu tertentu, sehingga memberikan stimulan kepada otot. Otot yang mendapatkan perlakuan terus-menerus akan beradaptasi dan memiliki daya tahan yang lebih baik. Tes yang dilakukan seperti tes kesemaptaan ABRI.

Profil kebugaran adalah gambaran kebugaran seseorang. Gambaran kebugaran diambil dari komponen kebugaran yang ada, seperti kekuatan, kelenturan, daya tahan, lemak, dan lain-lain (Defrizal Siregar (2009). Profil kebugaran digunakan untuk mengetahui tingkat kebugaran yang dimiliki seseorang, hal ini sangat dibutuhkan seorang instruktur fitness untuk memberikan program latihan yang tepat. Profil dalam penelitian ini adalah gambaran atau visualisasi kebugaran dari member. Gambaran tersebut dapat diambil komponen-komponen dalam pengambilan data kebugaran member di Fitness 
Center GOR FIK UNY Yogyakarta yang terdiri atas daya tahan jantung paru, fleksibilitas, kekuatan otot, dan lemak. Pengambilan data berkaitan dalam pemberian program, sehingga lebih fokus dengan tujuan yang dicapai. Profil kebugaran yang diambil dalam penelitian adalah:

1) Daya Tahan Jatung Paru

Daya tahan jantung paru dalam penelitian di ukur dengan menggunakan tes lari 12 menit. Tes tersebut menggunakan treadmill yang dimiliki oleh Fitness Center GOR FIK UNY Yogyakarta.

2) Fleksibilitas

Kelentukan dalam penelitian ini diukur dengan menggunakan alat fleksimeter.

3) Kekuatan Otot

Pengukuran kekuatan otot dalam penelitian ini menggunakan 1 RM. 1 RM adalah 1 repetisi maksimal, yaitu beban maksimal yang dapat diangkat seseorang hanya dalam hitungan satu kali angkatan.

4) Lemak

Lemak merupakan bahan atau zat yang dibutuhkan tubuh untuk menghasilkan energi. Lemak di simpan oleh tubuh sebagai cadangan energi yang paling besar, lemak di simpan pada jaringan bawah kulit. Simpanan lemak berasal dari konsumsi berlebihan salah satu atau kombinasi zat-zat: karbohidrat, lemak, dan protein. Lemak dibutuhkan bagi tubuh, apabila berlebihan, maka kurang baik bagi tubuh. Lemak berlebih yang tersimpan pada jaringan bawah kulit membuat seseorang terlihat gemuk dan kurang segar.

Pengukuran lemak menggunakan skinfold kaliper, dengan cara mengukur lipatan lemak pada bagian bawah kulit. Namun, saat ini sudah ada alat pengukur lemak yang lebih efisien. Alat pengukur lemak tersebut disebut fat monitor, alat ini menggunakan sistem bio elektrik dan dikombinasikan dengan data fisik seseorang (umur, jenis kelamin, tinggi badan, dan berat badan). Hasil pengukuran dikonversikan dengan norma yang telah ada, data ditunjukkan dalam bentuk persentase.

\section{Pengertian Latihan}

Prinsip latihan merupakan proses perubahan ke arah yang lebih baik, yaitu meningkatkan kualitas fisik, kemampuan fungsional tubuh, dan kualitas psikis seseorang. Latihan adalah suatu proses penyempurnaan kemampuan berolahraga yang berisi materi teori dan praktik, dengan metode, dan aturan pelaksanaan secara pendekatan ilmiah, memakai prinsip pendidikan yang terencana dan 
teratur, sehingga tujuan latihan dapat tercapai pada waktunya. Menurut Ade Rai (2006: 21) latihan adalah memberikan stimulus (rangsangan) untuk menciptakan kebutuhan-kebutuhan bagi tubuh untuk menyesuaikan diri (adaptasi). Latihan, baik latihan beban atau aerobik, merupakan aktivitas fisik yang menimbulkan tekanan yang berbeda bagi tubuh.

Menurut Djoko Pekik I (2000: 10) latihan kebugaran diartikan sebagai proses sistematis yang menggunakan rangsang gerak. Bertujuan meningkatkan atau mepertahankan kualitas fungsional tubuh, meliputi kualitas daya tahan jantung paru, kekuatan, daya tahan otot, kelentukan, dan komposisi tubuh.

Menurut Ade Rai, (2006: 01) untuk mencapai kebugaran fisik setidaknya ada tiga komponen yang perlu dimiliki, yaitu:

a. Kondisi aerobik yang baik

Aktivitas aerobik ialah semua aktivitas yang menggunakan banyak oksigen. Oksigen diantar ke seluruh tubuh dalam sistem kardiovaskuler yang terdiri atas jantung, paru-paru dan sirkulasi darah dalam peredaran darah. Sistem aerobik akan terlatih dengan baik dalam olahraga yang dilakukan dengan repetisi tinggi, seperti berlari, berenang dan bersepeda.

b. Fleksibilitas (Kelentukan)

Tubuh membutuhkan kelentukan agar tidak kaku. Seiring meningkatnya usia dan sedikit frekuensi latihan menyebabkan gerakan menjadi terbatas. Menurut Djoko Pekik I, (2000: 49) kelentukan adalah kemampuan persendian bergerak secara leluasa. Kelentukan sangat dibutuhkan seseorang untuk memudahkan dalam melakukan aktivitas sehari-hari maupun aktivitas berat. Tingkat kelentukan seseorang yang baik akan memberikan ruang gerak lebih luas.

c. Kondisi otot yang baik

Untuk memperkuat otot, cara yang efisien adalah latihan beban. Apabila berlatih beban, otot akan berkontraksi untuk menahan beban, sehingga otot beradaptasi terhadap beban tersebut dengan bertambah besar dan kuat.

\section{METODE PENELITIAN}

\section{Desain Penelitian}

Penelitian ini adalah penelitian deskriptif, artinya dalam penelitian ini hanya ingin menggambarkan situasi yang saat ini sedang berlangsung, tanpa pengujian hipotesis. Penelitian deskriptif ini merupakan penelitian yang dilakukan terhadap variabel mandiri tanpa membuat perbandingan atau menghubungkan dengan variabel lain.

Metode yang digunakan dalam penelitian ini menggunakan metode survey. Tujuan penelitian ini adalah untuk mengetahui kebugaran member pria fitness center GOR FIK-UNY Yogyakarta yang meliputi pengukuran daya tahan jantung paru, fleksibilitas, kekuatan otot, dan lemak. 
Populasi dalam penelitian ini adalah member pria fitness center GOR FIKUNY Yogyakarta umur 20 sampai 25 tahun dengan jumlah 20 orang.

Sampel yang digunakan dalam penelitian ini adalah member pria fitness center GOR FIK UNY, dengan jumlah keseluruhan 20 orang. Sampel diambil 20 orang karena dengan mempertimbangkan waktu penelitian, subjek yang diambil adalah member pria dengan batas umur 20 sampai 25 tahun.

Instrumen dalam penelitian adalah tes dan pengukuran. Tes dan pengukuran yang dilakukan adalah:

a. Daya tahan jantung paru menggunakan tes lari 12 menit dengan tredmill, jarak yang ditempuh dalam waktu 12 menit dicatat lalu dikonversikan ke tabel norma yang sudah ada. Tabel norma adalah norma cooper test yang diambil dari http://www.brianmac.co.uk/ VO2Max..htm\#VO2Max dan memiliki validitas 0.90 .

b. Kelentukan atau fleksibilitas menggunakan sit and reach test dengan alat fleksimeter, yaitu dengan menekuk tubuh seperti latihan mencium lutut. Jarak terjauh dari bekas jari yang ada dicatat dan dikonversikan pada tabel norma yang sudah ada. Tabel norma adalah norma sit and reach yang diambil dari Pedoman dan Modul Pelatihan Kesehatan Olahraga bagi Pelatih Olahragawan Pelajar. Departemen Pendidikan Nasional. Jakarta, (2000: 34). Tes tersebut memiliki validitas dan reliabilitas: face validity dan 0,92 .

c. Kekuatan otot menggunakan pengambilan beban 1RM, beban 1RM diambil menggunakan 5 jenis alat fitness yaitu chest press, leg press, vertical traction, lower back, dan arm curl. Beban 1RM yang didapatkan lalu dijumlahkan dan dibagi berat badan sehingga didapatkan kekuatan relatif. Kekuatan relatif ini lalu dikonversikan ke tabel norma yang sudah ada. Tabel norma adalah norma kekuatan absolut yang diambil dari Pedoman dan Modul Pelatihan Kesehatan Olahraga bagi Pelatih Olahragawan Pelajar.

d. Lemak diukur menggunakan alat body fat monitor. Hasilnya dalam bentuk angka yang keluar pada monitor, lalu dikonversikan pada tabel norma yang sudah ada. Tabel norma adalah norma fat and bidration monitor yang diambil dari table physical status relating fat and hydration ultimate gear dan memiliki validitas 0.71 .

\section{Hasil Penelitian}

Hasil tes kebugaran member pria Fitness Center GOR FIK UNY di deskripsikan berdasarkan masing-masing tes pengkuran yaitu: daya tahan jantung paru, kelentukan (fleksibilitas), kekuatan otot, dan lemak. Deskripsi hasil penelitian diuraikan sebagai berikut:

\section{Daya Tahan Jantung Paru $\left(\mathrm{VO}_{2}\right.$ Max $)$}

Tes daya tahan jantung paru diukur mengunakan tes lari 12 menit. Dari hasil penelitian 20 member pria fitness center GOR FIK yang dianalisis dengan 
bantuan software MS Exel dan SPSS 12.0 diperoleh rerata hasil tes $=34,395$; median $=32,30 ;$ modus $=28,20$ dan standard deviasi $=7,653$. Deskripsi hasil tes daya tahan jantung paru dapat dilihat pada tabel di bawah ini:

Tabel 1. Deskripsi Hasil Tes Daya Tahan Jantung Paru

\begin{tabular}{|l|c|c|c|}
\hline \multicolumn{1}{|c|}{ Kategori } & Absolute & F Relatif (\%) & F Komulatif \\
\hline Superior & 1 & 5 & 5.0 \\
\hline Excellent & 0 & 0 & 5.0 \\
\hline Good (Baik) & 1 & 5 & 10.0 \\
\hline Fair (Cukup) & 4 & 20 & 30.0 \\
\hline Poor (Buruk) & 3 & 15 & 45.0 \\
\hline $\begin{array}{l}\text { Very Poor (Sangat } \\
\text { Buruk) }\end{array}$ & 11 & 55 & 100.0 \\
\hline \multicolumn{1}{|c|}{ Jumlah } & 20 & 100 & - \\
\hline
\end{tabular}

Apabila ditampilkan dalam bentuk grafik terlihat pada gambar di bawah ini:

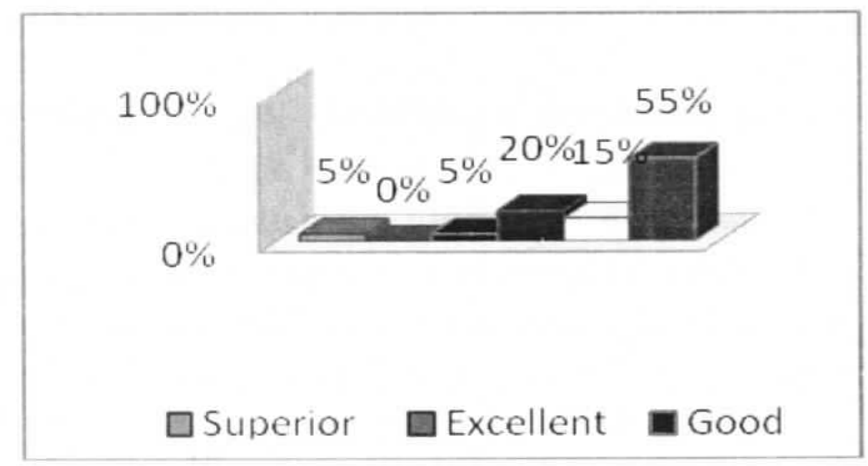

\section{Gambar 1. Grafik Hasil Tes Daya Tahan Jantung Paru}

Dari tabel dan gambar di atas diketahui kebugaran daya tahan jantung paru member pria finess center GOR FIK UNY berada pada kategori very poor (sangat buruk) sebesar $55 \%$ (11 orang), kategori fair (cukup) sebesar $20 \%$ (4 orang), kategori poor (buruk) sebesar $15 \%$ (3 orang), kategori superior dan good sebesar $5 \%$ (1 orang), dan tidak ada yang masuk dalam kategori eccellent.

\section{Kelentukan (Fleksibilitas)}

Kelentukan dalam penelitian ini diukur dengan menggunakan alat fleksimeter. Dari hasil penelitian 20 member pria fitness center GOR FIK yang dianalisis dengan bantuan software MS Exel dan SPSS 12.0 diperoleh rerata hasil tes = 24,325; 
Median $=22,75 ;$ Modus $=21,50 ;$ dan standard devias $i=4,749$. Deskripsi hasil tes kelentukan dapat dilihat pada tabel di bawah ini:

Tabel 2. Deskripsi Hasil Tes Kelentukan (Fleksibilitas)

\begin{tabular}{|l|c|c|c|}
\hline \multicolumn{1}{|c|}{ Kategori } & Absolute & F Relatif & F Komulatif \\
\hline Luar Biasa & 0 & 0 & 0 \\
\hline Sangat Bagus & 0 & 0 & 0 \\
\hline Bagus & 4 & 20 & 20.0 \\
\hline Baik & 5 & 25 & 45.0 \\
\hline Kurang & 11 & 55 & 100.0 \\
\hline Jumlah & 20 & $\mathbf{1 0 0}$ & - \\
\hline
\end{tabular}

Apabila ditampilkan dalam bentuk grafik terlihat pada gambar di bawah ini:

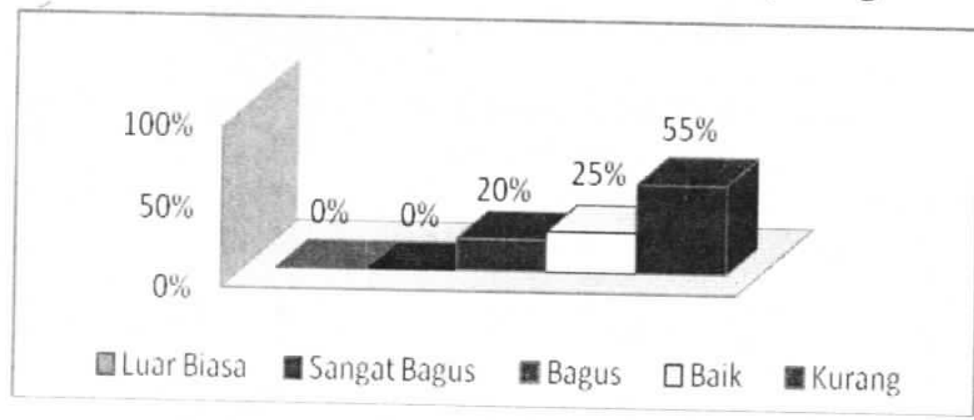

\section{Gambar 2. Grafik Hasil Tes Kelentukan (Fleksibilitas)}

Dari tabel dan gambar di atas diketahui hasil tes kelentukan member pria finess center GOR FIK UNY berada pada kategori kurang sebesar $55 \%$ (11 orang), kategori baik sebesar $25 \%$ (5 orang), kategori bagus sebesar $20 \%$ (4 orang) dan tidak ada yang masuk dalam kategori luar biasa dan sangat bagus.

\section{Kekuatan Otot}

Penelitian ini menggunakan pengambilan beban $1 \mathrm{RM}$ dari lima alat fitness yang mewakili otot-otot besar, yaitu chest press, vertical traction, lower back, leg press, dan arm curl. Selanjutnya beban maksimal yang didapat dijumlahkan dan dibagi berat badan, sehingga didapatkan kekuatan relatif. Dari hasil penelitian 20 member pria fitness center GOR FIK yang dianalisis dengan bantuan software MS Exel dan SPSS 12.0 diperoleh rerata hasil tes =4,681; Median=4,495; Modus = 4,90 dan standard deviasi $=1,136$. Deskripsi hasil tes kekuatan otot dapat dilihat pada tabel di bawah ini: 
Tabel 3. Deskripsi Hasil Tes Kekuatan Otot

\begin{tabular}{|l|c|c|c|}
\hline \multicolumn{1}{|c|}{ Kategori } & Absolute & F Relatif & F Komulatif \\
\hline Istimewa & 0 & 0 & 0 \\
\hline Baik & 0 & 0 & 0 \\
\hline Cukup & 6 & 30 & 30.0 \\
\hline Kurang & 5 & 25 & 55.0 \\
\hline Sangat kurang & 9 & 45 & 100.0 \\
\hline Jumlah & 20 & $\mathbf{1 0 0}$ & - \\
\hline
\end{tabular}

Apabila ditampilkan dalam bentuk grafik terlihat pada gambar di bawah ini:

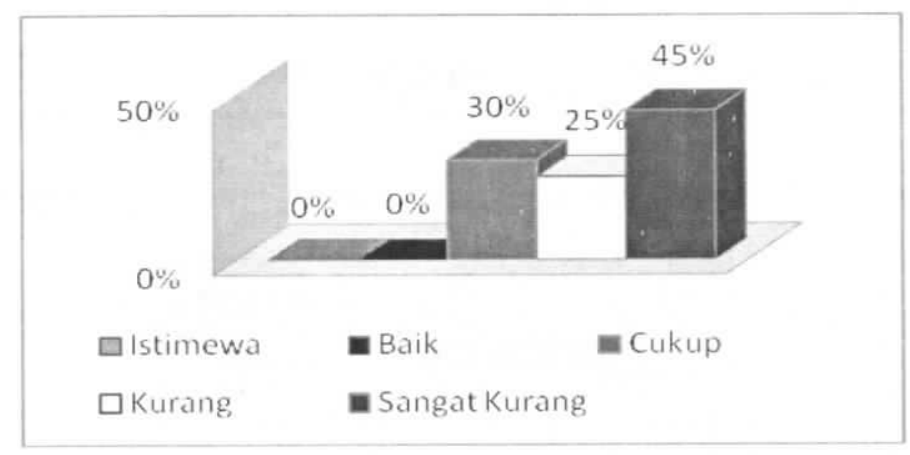

\section{Gambar 3. Grafik Hasil Tes Kekuatan Otot}

Dari tabel dan gambar di atas diketahui tes kekuatan otot member pria finess center GOR FIK UNY berada pada kategori sangat kurang sebesar $45 \%$ (9 orang), kategori cukup sebesar $30 \%$ (6 orang), kategori kurang sebesar $25 \%$ (5 orang), dan tidak ada yang masuk dalam kategori istimewa dan baik.

\section{Lemak}

Alat pengukur lemak dalam penelitian ini menggunakan fat monitor, alat ini mengukur kadar lemak yang terdapat dalam tubuh dengan memanfaatkan sensor elektrik tubuh dan dikombinasikan dengan data fisik seseorang ( umur, jenis kelamin, tinggi badan, berat badan). Dari hasil penelitian 20 member pria fitness center GOR FIK yang dianalisis dengan bantuan software MS Exel dan SPSS 12.0 diperoleh rerata hasil tes $=17,23 ;$ Median $=17,20 ;$ Modus $=4,10$ dan standard deviasi $=6,855$. Deskripsi hasil tes lemak dapat dilihat pada tabel di bawah ini: 
Tabel 4. Deskripsi Hasil Tes Lemak

\begin{tabular}{|l|c|c|c|}
\hline \multicolumn{1}{|c|}{ Kategori } & Absolute & F Relatif & F Komulatif \\
\hline Very High (Sangat Tinggi) & 5 & 25 & 25.0 \\
\hline High (Tinggi) & 3 & 15 & 40.0 \\
\hline Normal & 7 & 35 & 75.0 \\
\hline Lean (Kurus) & 2 & 10 & 85.0 \\
\hline Too Lean (Sangat Kurus) & 3 & 15 & 100.0 \\
\hline Jumlah & 20 & 100 & - \\
\hline
\end{tabular}

Apabila ditampilkan dalam bentuk grafik terlihat pada gambar di bawah ini:

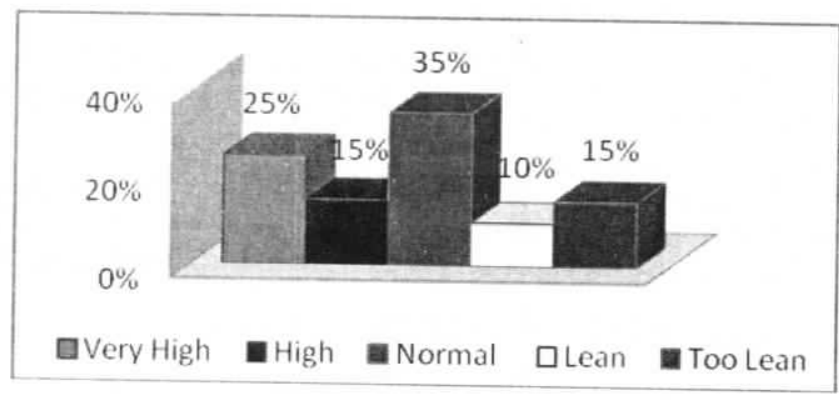

\section{Gambar 4. Grafik Hasil Tes Lemak}

Dari tabel dan gambar di atas diketahui tes lemak member pria finess center GOR FIK UNY berada pada kategori normal sebesar $35 \%$ (7 orang), very bigh (sangat tinggi) sebesar $25 \%$ (5 orang), kategori bigh (tinggi) dan too lean (sangat kurus) sebesar $15 \%$ (3 orang) dan kategori lean sebesar $10 \%$ ( 2 orang).

\section{Pembahasan}

Kebugaran merupakan kemampuan seseorang untuk dapat melakukan kerja seharihari secara efisien tanpa menimbulkan kelelahan yang berlebihan. Dalam penelitian ini kebugaran member fitness center di GOR FIK UNY di ukur dengan 4 komponen, yaitu daya tahan jantung paru, kelentukan, kekuatan otot dan lemak. Berdasarkan deskripsi hasil penelitian di atas dapat diuraikan sebagai berikut:

\section{Daya Tahan Jantung Paru}

Daya tahan jantung paru merupakan kemampuan tubuh untuk mengatasi kelelahan bekerja dalam waktu yang lama tanpa mengalami kelelahan berlebihan. Kebugaran seseorang dapat dikatakan baik apabila mempunyai daya tahan jantung paru. Daya tahan jantung paru dapat ditingkatkan dengan cara latihan, salah 
satunya latihan kebugaran, latihan fisik yang teratur akan menyebabkan peningkatan konsumsi oksigen yang semakin baik, sehingga daya tahan jantung akan meningkat.

Berdasarkan hasil penelitian di atas di peroleh daya tahan jantung paru member pria fitness center GOR FIK UNY sebagian besar masuk dalam kategori sangat buruk, hal tesebut diartikan kebugaran member pria diukur dari tes daya tahan jantung paru masih sangat buruk. Member yang masuk dalam kategori sangat buruk dan buruk dikarenakan latihan yang kurang intensif dan teratur, sehingga kebugarannya masih kurang dari cukup. Sedangkan member yang masuk dalam dalam kategori cukup, baik dan superior dikarenakan intensitas latihan yang rutin dan teratur, sehingga daya tahan jantung paru mereka stabil dan baik.

\section{Kelentukan}

Kelentukan merupakan kemampuan tubuh untuk melakukan gerakan secara optimal dan keleluasaan gerakan tubuh pada persendian yang sangat dipengaruhi oleh elastisitas otot, tendo, dan ligamen sekitar sendi dan sendi itu sendiri. Kelentukan dapat dijaga dengan melakukan peregangan pada awal latihan dan akhir latihan, sehingga semakin sering seseorang melakukan latihan, maka makin sering pula seseorang melatih kelentukannya, dan akan semakin baik. Agar kelentukan seseorang tetap baik, dapat dijaga dengan melakukan olahraga dan melatih fleksibilitas minimal 2 kali sehari.

Berdasarkan hasil penelitian di atas diperoleh kebugaran member pria fitness center GOR FIK UNY berdasarkan tes kelentukan sebagian besar masuk dalam kategori kurang, hal tersebut diartikan intensitas latihan beban pada member pria fitness center masih kurang dan perlu adanya peningkatan intensitas latihan, sedangkan yang masuk dalam kategori baik dan bagus, mempunyai intensitas latihan yang rutin dan teratur. Orang yang melakukan olahraga lebih sering dan teratur fleksibilitas tubuhnya lebih baik. Dikarenakan latihan yang dilakukan, pastilah akan melibatkan otot-otot tubuh untuk bergerak, sehingga kelentukan akan tetap terjaga dan tetap lentuk.

\section{Kekuatan Otot}

Kekuatan merupakan suatu komponen penting dalam melakukan aktivitas, dikarenakan kekuatan ialah kemampuan otot untuk mengatasi tahanan atau beban dalam menjalankan aktivitas. Untuk memperkuat otot tubuh dengan cara melakukan latihan setiap hari, dan cara yang efisien salah satunya dengan latihan beban.

Dalam penelitian ini, pengukuran kekuatan otot menggunakan pengambilan beban 1 RM dari lima alat fitness yang mewakili otot-otot besar, yaitu chest press, vertical traction, lower back, leg press, dan arm curl. Dari hasil penelitian diperoleh kekuatan otot member pria fitness center GOR FIK UNY sebagian besar masuk dalam kategori sangat kurang. 
Berdasarkan hasil penelitian member pria fitness center GOR FIK UNY yang masuk dalam kategori sangat kurang dan kurang diartikan kurang mempunyai kekuatan otot yang baik dan terlatih, dikarenakan intensitas latihan yang kurang, sedangkan yang masuk dalam kategori cukup, dikarenakan mereka melakukan latihan yang intensif sehingga kekuatan otot sudah beradaptasi dan meningkat.

Kekuatan tiap individu seseorang memang berbeda-beda bergantung pada kondisi fisik tiap infividu, akan tetapi kondisi fisik tersebut dapat dilatih. Seseorang yang sering berolahraga tubuhnya telah beradaptasi, sehingga kekuatan yang dimiliki menjadi lebih besar dan lebih baik dibanding dengan orang yang hanya melakukan kegiatan sehari-hari saja.

\section{Lemak}

Lemak merupakan bahan atau zat yang dibutuhkan tubuh untuk menghasilkan energi. Lemak di simpan oleh tubuh sebagai cadangan energi yang paling besar, lemak di simpan pada jaringan bawah kulit, tetapi lemak yang berlebihan kurang baik bagi tubuh dan akan menyebabkan kegemukan, sedangkan lemak yang kurang juga kurang baik karena akan membuat orang tampak kurus.

Kadar lemak seseorang dapat diatur dengan latihan atau olahraga yang teratur setiap hari. Pada penelitian ini alat yang digunakan untuk mengukur lemak adalah fat monitor, dengan cara memanfaatkan sensor elektrik tubuh dan dikombinasikan dengan data fisik seseorang ( umur, jenis kelamin, tinggi badan, berat badan).

Berdasarkan hasil penelitian di atas pengukuran lemak pada member pria fitness center GOR FIK UNY sebagian besar pada kategori normal. Member yang masuk dalam kategori normal, tinggi dan sangat tinggi mereka mempunyai kadar lemak yang bagus, artinya mereka menjaga kadar lemak mereka dengan baik dengan cara rutinitas latihan. Member yang masuk dalam kategori kurus dan sangat kurus, diartikan mempunyai kadar lemak yang kurang, sehingga perlu adanya peningkatan latihan, selain itu asupan makan juga perlu ditingkatkan. Kadar lemak sangat penting untuk menjaga penampilan, karena orang yang mempunyai kadar lemak kurang akan terlihat kurus dan orang yang mempunyai kadar lemak berlebihan akan terlihat gemuk.

\section{KESIMPULAN}

Dari penelitian yang dilakukan pada 20 orang member baru di Fitness Center GOR FIK UNY di peroleh hasil: daya tahan jantung paru $55 \%$ di kategori very poor (sangat buruk), kelentukan $55 \%$ di kategori kurang, kekuatan otot $45 \%$ di kategori sangat kurang, dan lemak $35 \%$ di kategori normal. Berdasarkan hasil penelitian diperoleh kesimpulan sebagai berikut: profil kebugaran member pria fitness center GOR FIK UNY Yogyakarta dari tes daya tahan jantung paru masuk dalam kategori very poor (sangat buruk), tes kelentukan masuk dalam kategori kurang, tes kekuatan otot masuk dalam kategori sangat kurang, tes lemak masuk dalam kategori normal. 
Berdasarkan kesimpulan di atas, maka program latihan yang lebih efisien adalah latihan physical fitness, kekuatan, body shaping, weight lost, dan latihan fleksibilitas. Analisa profil kebugaran tersebut lebih memudahkan seorang instruktur dalam memberikan program latihan yang tepat.

\section{DAFTAR PUSTAKA}

Ade Rai, dkk. "Gaya Hidup Sehat Fitnes dan Binaraga”. : Tabloid BOLA. 2006

Defrizal Siregar (2009). Faktor-faktor yang Mempengarubi Kebugaran. Diakses pada tanggal 18 Maret 2009. http://perdhana.wordpress.com/kebugaran jasmani$L$

Djoko Pekik I. (2000). Dasar-dasar Latihan Kebugaran. Yogyakarta: Lukman Offset. Junusul Hairy. (1989). Fisiologi Olahraga. Jakarta: Depdikbud.

Pusat Kesegaran Jasmani dan Rekreasi. (1999). Pedoman dan Modul Penataran Pelatib Fitness Center Tingkat Terampil. Jakarta: Depdiknas.

http://www.brianmac.co.uk/ VO2Max..htm\#VO2Max diunduh 5 Agustus 2008 